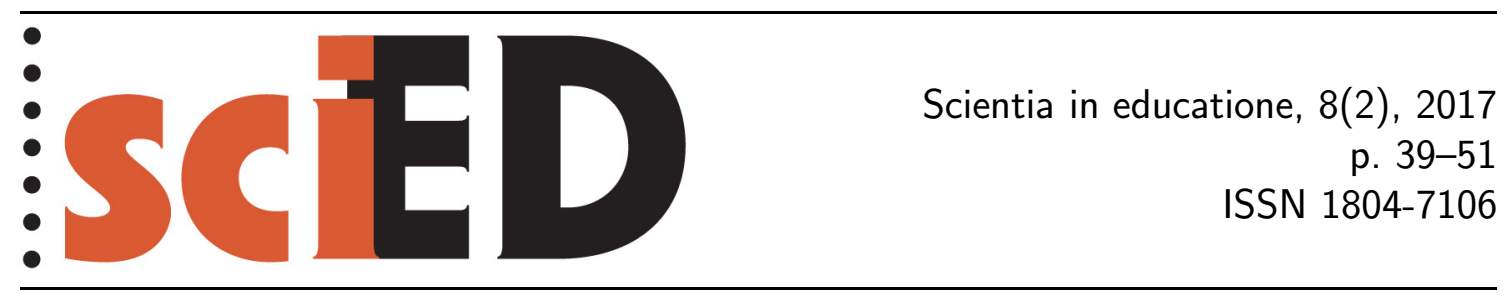

\title{
Dějiny přírodních věd: Jejich místo ve škole a v učebnicích biologie
}

\author{
Jana Hájková
}

\begin{abstract}
Abstrakt
Článek vychází z myšlenky, že by výuka dějin věd mohla přispět ke zlepšení vědecké gramotnosti žáků. Protože učitelé př́rodních věd nebývají př́liš znalí dějin vědy, opírají se při jejich výuce ve velké míře o učebnice. Popisovaný výzkum se proto zaměřil na sledování historického obsahu v českých učebnicích, $\mathrm{k}$ čemuž využil nástroj ověřený na portugalských učebnicích fyziky. Analyzovány byly učebnice biologie určené vyššímu gymnáziu z produkce nakladatelství Scientia, Fortuna a Olomouc. Výzkum ukázal, že se učebnice používané $\mathrm{v}$ dnešní době značně liší prostorem věnovaným dějinám, nicméně většina jich zmiňuje historii pouze okrajově. Obvykle jde o whigovské pojetí dějin, které ne vždy přispívá $\mathrm{k}$ vytvoření adekvátního obrázku o vývoji vědy.
\end{abstract}

Klíčová slova: dějiny vědy, učebnice biologie, vědecká gramotnost.

\section{History of Science: Its Role at School and its Place in Biology Textbooks}

\begin{abstract}
The article is based on an old idea that teaching history of science could improve pupils' scientific literacy. Since science teachers are usually not familiar with the history of science, they rely on textbooks. This research focused on historical content in Czech textbooks and made use of an instrument tested already on Portuguese physics textbooks. The research project analyzed biology textbooks for secondary school produced by three different publishers (Scientia, Fortuna, Olomouc). The results indicated substantial differences between the textbooks as far as history was concerned. Most of the textbooks under scrutiny mentioned the history of biology only briefly and they usually tended to the so-called Whig view of history.
\end{abstract}

Key words: history of science, biology textbooks, scientific literacy. 
Myšlenka, že by dějiny mohly být prospěšné pro výuku př́rodních věd (dále jen „věd“ ve smyslu „science“), není nová. Výrazněji se prosadila již ve 40. letech 20. století v USA (Solomon et al., 1992). Od té doby se objevila řada studií (viz Lederman, 1992), které porovnávaly výstupy výuky zohledňující dějinný vývoj vědy a výstupy výuky, která dějiny nebrala v úvahu. Zároveň nashromáždily argumenty pro i proti začleňování dějin do výuky věd.

Cílem výzkumu popisovaného v tomto článku bylo zjistit, jaký typ historických informací se nejčastěji vyskytuje v gymnaziálních učebnicích biologie a jakou roli $\mathrm{v}$ nich plní. Kvůli nedostatečným znalostem dějin vědy se totiž učitelé necítí při jejich výuce jistě a hodně se spoléhají na učebnice (Leite, 2002). Proto má smysl si všímat, jaký obrázek vývoje vědy žákům vykreslují učebnice.

Výzkumné otázky byly formulovány následovně:

1. Jsou v soudobých gymnaziálních učebnicích biologie zohledněny dějiny biologie?

2. Jaký typ informací $\mathrm{z}$ dějin biologie je $\mathrm{v}$ těchto učebnicích uveden?

3. Jakou formou jsou $\mathrm{v}$ učebnicích podány dějiny biologie?

4. Liší se jednotlivé učebnice prostorem věnovaným dějinám biologie?

\section{PřÍNOS VÝUKY DĚJIN VĚDY}

Již výše zmiňovaný Lederman (1992) podotýká, že ačkoliv neexistuje jednoznačný názor na to, jaký konkrétní obsah má být součástí výuky věd, panuje shoda, že jejím cílem je porozumění vědeckému způsobu poznávání. Tento cíl odpovídá požadavku na tzv. vědeckou gramotnost, která je podmíněna velkou rolí vědy a výzkumu v dnešní společnosti (Rutherford \& Ahlgren, 1990).

Vědeckou gramotnost je možné rozčlenit na porozumění (i) základním konceptům vědy; (ii) povaze vědy; (iii) vztahům mezi vědou a společenskými vědami; (iv) etice vědecké práce; (v) vztahům mezi vědou a společností a (vi) rozdílům mezi vědou a technikou (Pella et al., 1966). A právě dějiny vědy by mohly přispět $\mathrm{k}$ lepšímu porozumění uvedeným aspektům vědy (Rutherford, 2001). Dějiny vědy ukážou, že je vědecké poznání provizorní, že není tak objektivní, jak laická veřejnost soudí, a že její směřování ovlivňují nejrozmanitější společenské zájmy a osobní motivy (Leite, 2002). Také nás mohou poučit, že je mnoho způsobů, jak rozumět světu, a tím v žácích podnítit otázku: „Proč si myslíme zrovna tohle?“ (Monk \& Osborne, 1997). Dějiny vědy mohou vést $\mathrm{k}$ porozumění tomu, jak se navrhují experimenty a jak se z nich vyvozují závěry, a také $\mathrm{k}$ reflexi našich soudobých představ: díky historickým miskoncepcím si lépe uvědomíme naše vlastní (Wandersee, 1985, 1986), doceníme soudobé vědecké představy (Lin \& Hung, 2002), ale zároveň se zbavíme přezíravého pohledu na dřívější vědce (Irwin, 2000). Jinými slovy dějiny vědy nás mohou poučit o konceptuálních, procedurálních a kontextuálních aspektech vědy (Klopfer, 1969). Učit se vědu a učit se o vědě totiž není totéž (Matthews, 1994) a vědecky gramotný je jen ten, kdo ví, nejen k čemu věda dospěla, ale také jak to zjistila (Kyle, 1970). Bohužel učitelé se př́liš soustřed’ují na výsledek, $\mathrm{k}$ němuž věda dospěla, a opomíjejí proces, který k němu vedl (Wandersee, 1985).

Jak ukazují nedávné výzkumy, učitelé většinou dějiny vědy zmiňují v souvislosti se sociálními, politickými či psychologickými faktory ovlivňujícími vědu (Wang \& Marsh, 2002). Na střední škole využívají učitelé dějiny věd hlavně k tomu, aby žákům pomohli pochopit obsah a povahu vědeckého poznání, zatímco na základní škole s jejich pomocí spíš ukazují roli vědy ve společnosti a snaží se $\mathrm{k}$ ní vzbudit kladný vztah. (Wang \& Cox-Peterson, 2002). 
Pozitivní dopad dějin věd na výuku dokumentuje studie Lin a Hung (2002), podle které přispívají dějiny věd k prohloubení žákovské dovednosti řešit problémy. To ovšem pouze za předpokladu, že je historický přistup uplatňován dlouhodobě. Pouze dílčí úspěch dějin věd ve škole dokládá studie Solomona et al. (1992). Podle ní se přínos dějinně pojaté výuky věd omezil hlavně na to, že žáci začali lépe odlišovat teorie a fakta a opustili představu, že je pokus cílenou snahou učinit objev. Místo toho začali pokus pokládat za test navrženého vysvětlení, jehož výsledek vědci obvykle předjímají. Studie Abd-El-Khalick a Ledermana (2000) pak u vysokoškoláků vůbec neprokázala, že by znalost dějin vědy zlepšila studentské představy o povaze vědy.

O dějinách vědy se soudí, že by vedle vědecké gramotnosti mohly také přispět $\mathrm{k}$ sjednocení různých vědeckých pohledů na svět. Jak si povšiml již v 50. letech Snow (1959), mezi světem prrírodních věd a humanitními obory zeje obrovská propast plná neporozumění pro druhou stranu. Bylo by žádoucí najít prostředníka, který by tuto propast překlenul a roztřištěný svět stále víc specializovanějších věd sjednotil. Tímto prostř̌edníkem by mohly být právě dějiny vědy (Wang \& Cox-Peterson, 2002; Matthews, 1994).

Dějiny navíc zohledňují společenský rozměr vědy, ukazují, že je věda kolektivním výsledkem práce lidí ukotvených v určitém dobovém kontextu (Leite, 2002) a že odráží individuální i společenské potřeby. V tomto smyslu historie vědu humanizuje (Wang \& Cox-Peterson, 2002). K tomu, aby věda nebyla chladná a nepropojená s lidskými osudy, mohou přispět například biografické zmínky o úspěších i selháních objevitelů (Leite, 2002). Dějiny tak mohou na žáky působit motivačně a vyvolat dojem, že je věda skutečné intelektuální dobrodružství (Slezak, 1994), kde jsou dramatické změny pravidlem, ne výjimkou (Wang \& Marsh, 2002). Větší motivovanost žáků $\mathrm{k}$ vědecké práci, která byla podmíněná integrací historie do výuky věd, doložili např́íklad Klopfer a Cooley (1961).

\section{POTÍŽE S VÝUKOU DĚJIN VĚDY}

Jakkoliv jsou výše uvedené argumenty pro zapojení dějin vědy do výuky pádné, situaci komplikuje několik skutečností:

Lederman (1992) poukazuje, že se pojetí vědy liší jak v rámci jednotlivých přírodovědných disciplín, tak mezi jednotlivými filosofy a historiky vědy. Proto nepovažuje za možné chtít po učitelích, aby žákům představili jednu konkrétní („,tu správnou“) podobu vědy. Ř́ká, že by spíš měli zprostředkovat rozmanitost povahy věd a jejich proměnlivost $\mathrm{v}$ čase.

V souladu s názory T. S. Kuhna upozorňují Abd-El-Khalick a Lederman (2000), že je každý člověk ukotven v soudobém paradigmatu, a aby se z dějin vědy poučil, musí dokázat přepnout na jiný (dobový) způsob myšlení. A to je u žáků s omezenými znalostmi dějin těžko uskutečnitelné.

Ryze praktickou komplikaci pro učitele představuje skutečnost, že se porozumění povaze vědy obtížně testuje (Irwin, 2000) a že je př́rodovědné kurikulum i bez dějin věd dost obsáhlé. Před učitelem tak vyvstává nelehký úkol, co z dějin vědy vybrata jak je interpretovat, aby se z nich nestaly „historické anekdoty“ (Holton, 2003).

Historický př́stup $\mathrm{k}$ výuce vědy naráží také na neadekvátní znalosti povahy vědy a jejích dějin na straně učitelů. Protože informace o povaze vědy vyvozují žáci často podvědomě ze slov a činů svého učitele, z tzv. skrytého vědeckého kurikula (Hodson, 1986), je nanejvýš nutné, aby měl učitel patřičnou představu o povaze vědy i o jejích dějinách a vědomě svoje působení na žáky směroval. Adekvátní představa 
o povaze vědy se však nemusí promítnout do každodenní praxe učitele (Lederman, 1995). Je sice nezbytnou, nikoliv však postačující podmínkou, aby ji učitelé mohli šiřit dál (Lederman, 1992). Uvedený názor potvrzuje studie Wang a Cox-Petersona (2002), podle které učitelé význam dějin vědy doceňují, ale v jejich výuce se to př́liš neprojevuje.

\section{MetodikA}

Zohlednění dějin biologie bylo zkoumáno v učebnicích biologie pro vyšší gymnázium, s nimiž se ve školním roce 2016/2017 mohl středoškolák běžně setkat v knihkupectvích. Jednalo se o produkci nakladatelství Scientia, Fortuna a Olomouckého nakladatelství. Celkem bylo analyzováno 13 učebnic, přičemž dvanáct z nich se zaměřovalo na určitý biologický obor (např. botaniku či biologii člověka). Protože poslední učebnice (Biologie pro gymnázia z Olomouckého nakladatelství) zahrnovala učivo celé středoškolské biologie, byla rozdělena na pět částí odpovídající délkou a zaměřením jednooborovým učebnicím ostatních nakladatelství. Testové otázky zahrnuté v praktické části této učebnice byly vždy započítány do odpovídajícího oboru.

Následuje seznam analyzovaných učebnic a jejich písmenného značení:

A - Kočárek, E. (2010). Biologie člověka 1. Praha: Scientia.

B - Kočárek, E. (2010). Biologie člověka 2. Praha: Scientia.

C - Kočárek, E. (2008). Genetika. Praha: Scientia.

D - Závodská, R. (2006). Biologie buněk. Praha: Scientia.

E - Papáček, M. et al. (2000). Zoologie. Praha: Scientia.

F - Kubát, K. et al. (2003). Botanika. Praha: Scientia.

G - Novotný, I. \& Hruška, M. (2005). Biologie člověka. Praha: Fortuna.

H - Smarda, J. (2003). Genetika. Praha: Fortuna.

CH - Kubišta, V. (2000). Obecná biologie. Praha: Fortuna.

I - Smrž, J., Horáček, I. \& Švátora, M. (2004). Biologie živočichů. Praha: Fortuna.

J - Kincl, L., Kincl, M. \& Jakrlová, J. (2008). Biologie rostlin. Praha: Fortuna.

K - Šlégl, J., Kislinger, F. \& Laníková, J. (2002). Ekologie a ochrana životního prostředí. Praha: Fortuna.

L - Jelínek, J. \& Zicháček, V. (2014). Biologie pro gymnázia. Olomouc: Nakladatelství Olomouc.

L1 - část Biologie prokaryot, rostlin a hub.

L2 - část Chromista a prvoci.

L3 - část Biologie živočichů.

L4 - část Biologie a fyziologie člověka (Je v ní z velké části zakomponována i genetika.)

L5 - část Vybrané kapitoly z obecné biologie.

V analýze nebyly zahrnuty dvě učebnice z produkce Olomouckého nakladatelství: (Zicháček, V. 2012. Zoologie. Olomouc: Nakladatelství Olomouc., Jelínek, J. 2011. Vybrané kapitoly z obecné biologie. Olomouc: Nakladatelství Olomouc.). Jejich obsah totiž odpovídá částem učebnice Biologie pro gymnázia (L3 a L5), tudíž jejich zahrnutí do výzkumu by znamenalo dvojité hodnocení téhož materiálu a zkreslení celkového obrazu dostupných učebnic. 
Pro sledování historického obsahu v přírodovědných učebnicích byl využit nástroj navržený pro analýzu portugalských učebnic fyziky (Leite, 2002: s. 343-345). Základní sledované kategorie (typ historické informace, způsob její prezentace, kontext, význam historické informace, související učební aktivity, způsob začlenění dějin do učebnice a jejich zohlednění v bibliografii) byly přejaté beze změn. S ohledem na specifika učebnic biologie byly upraveny některé dílčí kategorie, např́klad byla nově přidána interpretace jevu, sledován byl také terminologický kontext, upraveny byly způsoby zařazení historických pasáží do učebnic. V tabulce 1 uvádím popis sledovaných kategorií. Pro porovnání s původní podobou navrženého nástroje odkazuji čtenáře na článek Leite (2002: s. 343-345).

Tab. 1: Kategorie sledované v učebnicích

Specifikace sledovaných

Podrobnější komentář

historických informací

\begin{tabular}{|c|c|c|}
\hline \multicolumn{3}{|l|}{ Typ historické informace } \\
\hline Vědci & & \\
\hline & Jméno & $\begin{array}{l}\text { Uvedené i bez křestního jména } \\
\text { a životních dat. }\end{array}$ \\
\hline & Osobnost & $\begin{array}{l}\text { Např́íklad vlastnosti vědce, jeho povaha } \\
\text { apod. }\end{array}$ \\
\hline & $\begin{array}{l}\text { Události } \\
\text { ze života }\end{array}$ & $\begin{array}{l}\text { Životopisné pasáže, informace } \\
\text { o přátelství s určitou osobou, } \\
\text { o rodinném zázemí, ... }\end{array}$ \\
\hline & $\begin{array}{l}\text { Pozitivní } \\
\text { hodnocení }\end{array}$ & $\begin{array}{l}\text { Zmínky o výjimečnosti vědce nebo jeho } \\
\text { dobrých činech. }\end{array}$ \\
\hline & $\begin{array}{l}\text { Negativní } \\
\text { hodnocení }\end{array}$ & $\begin{array}{l}\text { Zmínky o podprůměrných školních } \\
\text { výsledcích, nešikovnosti apod. }\end{array}$ \\
\hline \multicolumn{3}{|l|}{ Vývoj vědy } \\
\hline & Objev & $\begin{array}{l}\text { Zmínky o objevu, vynálezu či nové } \\
\text { myšlence, pozorování jevu (i nemoci), } \\
\text { navržení nového léčebného postupu atd. }\end{array}$ \\
\hline & Popis objevu & $\begin{array}{l}\text { Bližší informace o průběhu pokusů či } \\
\text { o okolnostech objevu. }\end{array}$ \\
\hline & $\begin{array}{l}\text { Interpretace } \\
\text { jevu }\end{array}$ & $\begin{array}{l}\text { Nový přistup či výklad určitého jevu, } \\
\text { teorie nově vysvětlující známý jev. }\end{array}$ \\
\hline & $\begin{array}{l}\text { Lineární pojetí } \\
\text { vývoje vědy }\end{array}$ & $\begin{array}{l}\text { Sled objevů bez návaznosti či vysvětlení } \\
\text { souvislostí, historický přehled etap, } \\
\text { zdánlivě plynulý vývoj mírící } \\
\text { k dnešnímu stavu poznání. }\end{array}$ \\
\hline & $\begin{array}{l}\text { Realistické } \\
\text { pojetí vývoje } \\
\text { vědy }\end{array}$ & $\begin{array}{l}\text { Popis obtíží, tápání, dobových diskusí } \\
\text { a peripetií při prosazování určitého } \\
\text { př́istupu, střety protichůdných názorů. }\end{array}$ \\
\hline \multicolumn{3}{|l|}{$\begin{array}{l}\text { Zodpovědné } \\
\text { osoby }\end{array}$} \\
\hline & Jednotlivec & $\begin{array}{l}\text { Vědec jako samostatně pracující osoba, } \\
\text { které se dá objev připsat. }\end{array}$ \\
\hline & Skupina & $\begin{array}{l}\text { Dva a více vědců spolupracujících na } \\
\text { stejném úkolu. }\end{array}$ \\
\hline & $\begin{array}{l}\text { Vědecká } \\
\text { komunita }\end{array}$ & $\begin{array}{l}\text { Výsledky připisovány vědcům dané } \\
\text { doby bez uvedení konkrétních postav. }\end{array}$ \\
\hline
\end{tabular}


Způsob prezentace

historické informace

\begin{tabular}{ll}
\hline Obrázek vědce & Fotografie či kresba vědce. \\
\hline Obrázky ostatní & $\begin{array}{l}\text { Fotografie či kresba př́stroje, interiéru } \\
\text { a vybavení laboratoře, titulní strany } \\
\end{array}$ \\
& knihy, ... \\
\hline Původní & Text či nákres, jehož autorem je \\
dokument & zmiňovaný vědec. Započítány jsou \\
& i krátké citáty. \\
\hline Text autora & Jde o souvislý text psaný autorem \\
& učebnice, včetně popisu dobových \\
& pokusů,... \\
\hline
\end{tabular}

Kontext historické

informace

\begin{tabular}{|c|c|c|}
\hline & Vědecký & $\begin{array}{l}\text { Historická informace má podobu } \\
\text { vědeckého poznání. }\end{array}$ \\
\hline & Technologický & $\begin{array}{l}\text { Historie je uvedena v souvislosti } \\
\text { s dostupností či naopak absencí } \\
\text { potřebné technologie. Může jít i o nový } \\
\text { léčebný postup. }\end{array}$ \\
\hline & Sociální & $\begin{array}{l}\text { Historická pasáž vypovídá o životních } \\
\text { podmínkám dané doby, obecně } \\
\text { přijímaných postojích, ... }\end{array}$ \\
\hline & Politický & $\begin{array}{l}\text { Historická nformace odrážíi tehdejší } \\
\text { politické dění. }\end{array}$ \\
\hline & Náboženský & $\begin{array}{l}\text { Historická informace se vztahuje } \\
\text { k tehdejším náboženským představám. }\end{array}$ \\
\hline & Terminologický & $\begin{array}{l}\text { Je zmiňován původ pojmů, jejich první } \\
\text { použití, př́padně změna jejich významu } \\
\text { v čase. }\end{array}$ \\
\hline & Epistemologický & $\begin{array}{l}\text { Jsou zmíněny dobové postupy vědecké } \\
\text { práce a zpo̊sobu poznávání vůbec. } \\
\text { Poukazuje se na omezení vědeckých } \\
\text { metod, na případy podvodů, spory } \\
\text { o oprávněnost ocenění určitého objevu } \\
\text { apod. }\end{array}$ \\
\hline \multicolumn{3}{|l|}{$\begin{array}{l}\text { Význam historické } \\
\text { informace }\end{array}$} \\
\hline & $\begin{array}{l}\text { Informace } \\
\text { v základním } \\
\text { textu }\end{array}$ & $\begin{array}{l}\text { Historická informace je součástí } \\
\text { základního textu. }\end{array}$ \\
\hline & $\begin{array}{l}\text { Informace } \\
\text { v doplňujícím } \\
\text { textu }\end{array}$ & $\begin{array}{l}\text { Historická pasáž je určena zájemcům. } \\
\text { Obvykle je tištěna drobnějším písmem či } \\
\text { jinak vyznačena. Může být soustředěna } \\
\text { do vyhrazených částí učebnice (př́lohy, } \\
\text { graficky odlišené boxy, ... .). }\end{array}$ \\
\hline
\end{tabular}




\begin{tabular}{|c|c|c|}
\hline \multicolumn{3}{|l|}{$\begin{array}{l}\text { Učební aktivity } \\
\text { související s historií }\end{array}$} \\
\hline & Průzkum & Úkol vedoucí žáky k vyhledání \\
\hline & literatury & $\begin{array}{l}\text { literatury či jiného informačního zdroje } \\
\text { a vypracování slohové práce či } \\
\text { přednesení referátu. }\end{array}$ \\
\hline & Rozbor dat & $\begin{array}{l}\text { Analýza údajů získaných z dobového } \\
\text { pokusu. }\end{array}$ \\
\hline & $\begin{array}{l}\text { Zopakování } \\
\text { historického } \\
\text { pokusu }\end{array}$ & $\begin{array}{l}\text { Výzva k zopakování dobového pokusu, } \\
\text { návod na jeho provedení. }\end{array}$ \\
\hline & Otázky & $\begin{array}{l}\text { Otázky testující zapamatování } \\
\text { historických informací uvedených } \\
\text { v učebnici. }\end{array}$ \\
\hline & Ostatní & $\begin{array}{l}\text { Např́klad výzva k exkurzi (návštěvě } \\
\text { muzea) apod. }\end{array}$ \\
\hline \multicolumn{3}{|l|}{$\begin{array}{l}\text { Způsob zařazení } \\
\text { historických pasáží }\end{array}$} \\
\hline Systematické & & $\begin{array}{l}\text { V celé učebnici je historie biologie } \\
\text { zakomponována jednotně. Historické } \\
\text { pasáže jsou téměř ve všech kapitolách. }\end{array}$ \\
\hline \multicolumn{3}{|l|}{ Nepravidelné } \\
\hline & $\begin{array}{l}\text { Jedna historická } \\
\text { kapitola }\end{array}$ & $\begin{array}{l}\text { Kromě historické kapitoly (úvodu, } \\
\text { předmluvy, přílohy apod.) jsou } \\
\text { historické zmínky v učebnici ojedinělé. }\end{array}$ \\
\hline & $\begin{array}{l}\text { Sporadické } \\
\text { zmínky } \\
\text { o historii }\end{array}$ & $\begin{array}{l}\mathrm{V} \text { učebnici jsou na několika málo } \\
\text { místech uvedeny historické informace. }\end{array}$ \\
\hline & $\begin{array}{l}\text { Častější } \\
\text { historické } \\
\text { pasáže }\end{array}$ & $\begin{array}{l}\text { V učebnici jsou do některých kapitol } \\
\text { zakomponovány obsáhlejší historické } \\
\text { pasáže. }\end{array}$ \\
\hline Žádné & & $\begin{array}{l}\text { Učebnice postrádá historické informace. } \\
\text { V celém textu se objeví maximálně } \\
\text { jedna až dvě zmínky. }\end{array}$ \\
\hline \multicolumn{3}{|l|}{ Bibliografie k historii } \\
\hline & $\begin{array}{l}\text { Tištěné } \\
\text { publikace }\end{array}$ & $\begin{array}{l}\text { Soupis knih či článků věnovaných } \\
\text { dějinám biologie, bud’ v použité, nebo } \\
\text { v doporučené literatuře. }\end{array}$ \\
\hline & Internet & $\begin{array}{l}\text { Odkazy na webové stránky vztahující se } \\
\text { k historickým tématům. }\end{array}$ \\
\hline
\end{tabular}

Při analýze nebyla vyhodnocována věcná správnost a přesnost historických informací, pouze se zaznamenávala četnost výskytu sledovaných významových jednotek. Základním vyhodnocovaným úsekem textu byl odstavec, který přirozeně nese ucelenou myšlenku či informaci. Do analýzy byly započítávány i události z nedávné minulosti. V př́padě, že se historická informace opakovala (např́klad byla-li zmíněna v textu a následně i v závěrečném shrnutí kapitoly), byla počítána pouze jednou. Obdobně nebyla počítána opakující se jména téhož vědce. 


\section{VÝSLEDKY}

Analýza výše uvedených učebnic biologie přinesla následující údaje:

Jak ukazuje tabulka 2 , v historických pasážích jsou ve většině učebnic zmiňováni vědci zodpovědní za určitý objev. Jejich počet se v jednotlivých učebnicích velmi liší. Výrazně nadprůměrné hodnoty vykazují učebnice $\mathrm{A}$ a $\mathrm{C}$, které mají stejného autora. Ten v předmluvě k učebnici C uvádí, že poznatky v učebnici mají „ilustrovat vývoj genetického poznání od samých počátků až do současnosti. Proto je ve většině kapitol zdůrazněn historický aspekt, který často přispívá i k lepšímu pochopení učiva“. (Kočárek, 2008: s. 7). V předmluvě k učebnici A se vyjadřuje obdobně. Zdůrazňování dějin biologie $\mathrm{v}$ obou učebnicích tedy vyplývá z přesvědčení jejich autora.

Tab. 2: Typ historické informace

A B C D E F G H CH I J K L1 L2 L3 L4 L5 suma

Vědci

\begin{tabular}{|c|c|c|c|c|c|c|c|c|c|c|c|c|c|c|c|c|c|}
\hline & Jméno & 103 & 144 & 3 & 3 & 08 & 15 & 22 & 1617 & 3 & 0 & 0 & 14 & 2 & & & $\overline{303}$ \\
\hline & Osobnost & 0 & 0 & 2 & 0 & $\begin{array}{lll}0 & 0\end{array}$ & 0 & 0 & 100 & 0 & 0 & 0 & ( & & & 0 & 3 \\
\hline & $\begin{array}{l}\text { Události } \\
\text { ze života }\end{array}$ & 6 & 0 & 3 & 0 & 00 & 0 & 0 & 000 & 0 & 0 & 0 & & 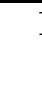 & & 1 & 11 \\
\hline & $\begin{array}{l}\text { Pozitivní } \\
\text { hodnocení }\end{array}$ & 2 & 0 & 1 & 0 & 00 & 0 & 0 & 300 & 0 & 0 & 0 & & ( & & 0 & 6 \\
\hline & $\begin{array}{l}\text { Negativní } \\
\text { hodnocení }\end{array}$ & 0 & 0 & 1 & 0 & 00 & 0 & 0 & $\begin{array}{llll}0 & 0 & 0\end{array}$ & 0 & 0 & 0 & & ( & & $\overline{0}$ & 1 \\
\hline \multicolumn{18}{|l|}{ Vývoj vědy } \\
\hline & Objev & 41 & 32 & 22 & 9 & 03 & 6 & 12 & $\begin{array}{lll}915 \\
\end{array}$ & 2 & 0 & 0 & & 12 & & 1 & 130 \\
\hline & Popis objevu & 9 & 0 & 3 & 1 & 00 & 1 & 2 & $\begin{array}{lll}0 & 0 & 0 \\
\end{array}$ & 0 & 0 & 0 & & . & & 1 & 18 \\
\hline & $\begin{array}{l}\text { Interpretace } \\
\text { jevu }\end{array}$ & 22 & 2 & 4 & 0 & 00 & 0 & 0 & 100 & 0 & 0 & 0 & & & & 1 & 44 \\
\hline & $\begin{array}{l}\text { Lineární pojetí } \\
\text { vývoje vědy }\end{array}$ & 4 & 2 & 8 & 2 & 02 & 1 & 4 & 501 & 0 & 0 & 0 & & ( & ) & 0 & 29 \\
\hline & $\begin{array}{l}\text { Realistické } \\
\text { pojetí vývoje } \\
\text { vědy }\end{array}$ & 6 & 1 & 4 & 1 & 00 & 0 & 1 & 100 & 0 & 0 & 0 & & & ) & 0 & 14 \\
\hline \multicolumn{18}{|c|}{ Zodpovědné osoby } \\
\hline & Jednotlivec & 44 & 7 & 6 & 7 & 03 & 4 & 5 & 713 & 1 & 0 & 0 & & 1 & & 4 & 105 \\
\hline & Skupina & 11 & 0 & 6 & 2 & 00 & 3 & 3 & 101 & 1 & 0 & 0 & & & & 1 & 37 \\
\hline & $\begin{array}{l}\text { Vědecká } \\
\text { komunita }\end{array}$ & 2 & 3 & 2 & 0 & 00 & 0 & 1 & 101 & 0 & 0 & 0 & & & & 0 & $\overline{10}$ \\
\hline
\end{tabular}

Vědci, kteří byli zmíněni v největším počtu učebnic (bez ohledu na to, kolikrát se jejich jméno opakovalo), byli Ch. Darwin v souvislosti s evoluční teorií a C. Linné v souvislosti se základy systematiky a pravidly pojmenovávání organismů. Oba byli uvedeni v sedmi učebnicích. Těsně za nimi následují M. J. Schleiden a T. Schwann, které uvedlo v souvislosti s buněčnou teorí šest učebnic.

Z tabulky 2 vyplývá, že o vědcích píší autoři učebnic vesměs neutrálně, hodnocení jejich osobnosti a činů, at již kladné či záporné, je ojedinělé. Také obvykle nevěnují pozornost událostem z jejich života. Vědec bývá zmíněn v souvislosti s určitým objevem či myšlenkou, méně často v souvislosti s novou interpretací známého jevu. Objev bývá jen konstatován, jeho okolnosti, související pokusy a návaznost na předchozí či následující bádání obvykle rozebírány nejsou. Je-li objev ojediněle 
zasazen do dobového vývoje vědy, je tento vývoj většinou podán jako sled objevů postupně vedoucích $\mathrm{k}$ dnešnímu stavu poznání. Realistické vykreslení křivolakého vývoje se v učebnicích objevuje sporadicky. Objev bývá nejčastěji připisován samostatně pracujícímu vědci.

Pro orientační porovnání se situací na základní škole a nižším gymnáziu doplňme, že v učebnicích nakladatelství Fraus (Čabradová, V. et al. 2003. Přírodopis 6. Plzeň: Fraus; Čabradová, V. et al. 2005. Přírodopis 7. Plzeň: Fraus; Vaněčková, I. et al. 2006. Př́rodopis 8. Plzeň: Fraus; Švecová, M., Matějka, D. 2007. Př́rodopis 9. Plzeň: Fraus) bylo dohromady uvedeno 15 různých osobností z dějin biologie, přičemž pět z nich bylo spjato s Českem - J. E. Purkyně, J. Janský, A. Hrdlička, J. Barrande a G. Mendel. Nejvíce osobností bylo uvedeno v učivu o člověku (12). Nejčastěji byli zmiňováni C. Linné, A. van Leeuwenhoek, J. Barrande a J.E. Purkyně, kteří se objevili ve dvou učebnicích.

Tab. 3: Způsob prezentace historické informace

\begin{tabular}{lrrrrrrrrrrrrrrrrrrr}
\hline & A & B & C & D & E & F & G & H & CH & I J & K L1 & L2 & L3 & L4 & L5 suma \\
\hline Obrázek vědce & 8 & 1 & 9 & 1 & 0 & 0 & 0 & 0 & 4 & 0 & 0 & 0 & 0 & 0 & 0 & 19 & 0 & $\mathbf{4 2}$ \\
\hline Obrázky ostatní & 0 & 0 & 2 & 0 & 0 & 0 & 0 & 0 & 0 & 0 & 1 & 0 & 0 & 0 & 0 & 3 & 1 & $\mathbf{7}$ \\
\hline $\begin{array}{l}\text { Po̊vodní } \\
\text { dokument }\end{array}$ & 7 & 2 & 1 & 1 & 0 & 0 & 1 & 1 & 1 & 0 & 0 & 0 & 0 & 0 & 0 & 0 & 1 & $\mathbf{1 5}$ \\
\hline Text autora & 81 & 18 & 31 & 9 & 0 & 3 & 7 & 13 & 9 & 1 & 5 & 2 & 0 & 0 & 7 & 15 & 14 & $\mathbf{2 1 5}$ \\
\hline
\end{tabular}

Z tabulky 3 vyplývá, že s historií se žáci nejčastěji seznamují prostřednictvím textů autora učebnice. Při dokreslení tématu se občas uplatní podobizny vědců. Jiné způsoby, jak historickou látku žákům předložit, se využívají minimálně.

Tab. 4: Kontext historické informace

\begin{tabular}{lrrrrrrrrrrrrrrrrrrrrr}
\hline & A & B & C & D E & F & G & H & CH & I J J K & L1 & L2 & L3 & L4 & L5 suma suma \\
\hline Vědecký & 54 & 3 & 20 & 7 & 0 & 2 & 7 & 13 & 7 & 1 & 5 & 1 & 0 & 0 & 4 & 14 & 14 & $\mathbf{1 5 2}$ \\
\hline Technologický & 17 & 13 & 5 & 2 & 0 & 0 & 1 & 2 & 4 & 0 & 0 & 0 & 0 & 0 & 2 & 2 & 0 & $\mathbf{4 8}$ \\
\hline Sociální & 17 & 1 & 12 & 0 & 0 & 0 & 0 & 1 & 1 & 0 & 0 & 0 & 0 & 0 & 0 & 0 & 1 & $\mathbf{3 3}$ \\
\hline Politický & 2 & 0 & 1 & 0 & 0 & 0 & 0 & 1 & 0 & 0 & 0 & 0 & 0 & 0 & 0 & 0 & 0 & $\mathbf{4}$ \\
\hline Náboženský & 6 & 0 & 0 & 0 & 0 & 0 & 0 & 0 & 0 & 0 & 0 & 0 & 0 & 0 & 0 & 0 & 0 & $\mathbf{6}$ \\
\hline Terminologický & 10 & 0 & 5 & 1 & 0 & 1 & 1 & 1 & 0 & 0 & 0 & 1 & 0 & 0 & 3 & 1 & 1 & $\mathbf{2 5}$ \\
\hline Epistemologický & 5 & 0 & 0 & 0 & 0 & 0 & 0 & 0 & 2 & 0 & 0 & 0 & 0 & 0 & 0 & 0 & 0 & $\mathbf{7}$ \\
\hline
\end{tabular}

Historické informace jsou v učebnicích uváděny nejčastěji v souvislosti se změnou vědeckého poznání, méně často v souvislosti s pokrokem technologií (viz tab. 4). Ve většině učebnic bývá alespoň jedna zmínka vysvětlující původ určitého biologického termínu.

Tabulka 5 ukazuje, že většina autorů umísţuje historické informace do pasáží určených pro zájemce. Tyto úseky bývají graficky odděleny od hlavního textu.

Tab. 5: Význam historické informace

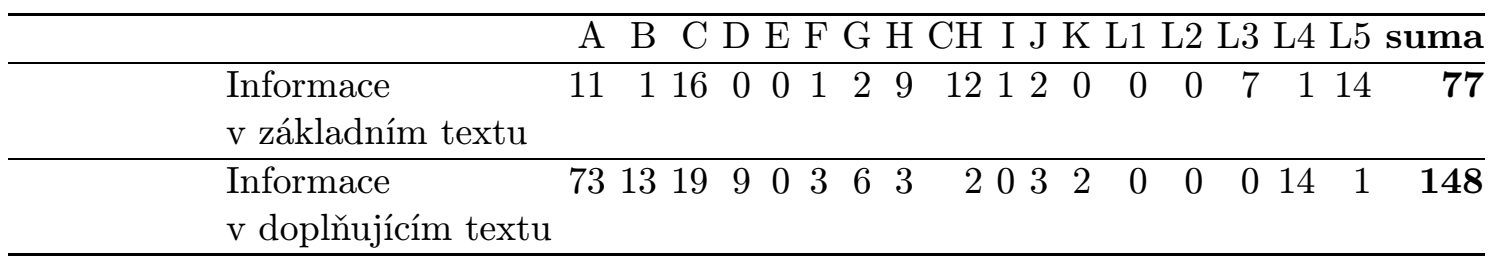


Tab. 6: Učební aktivity související s historií

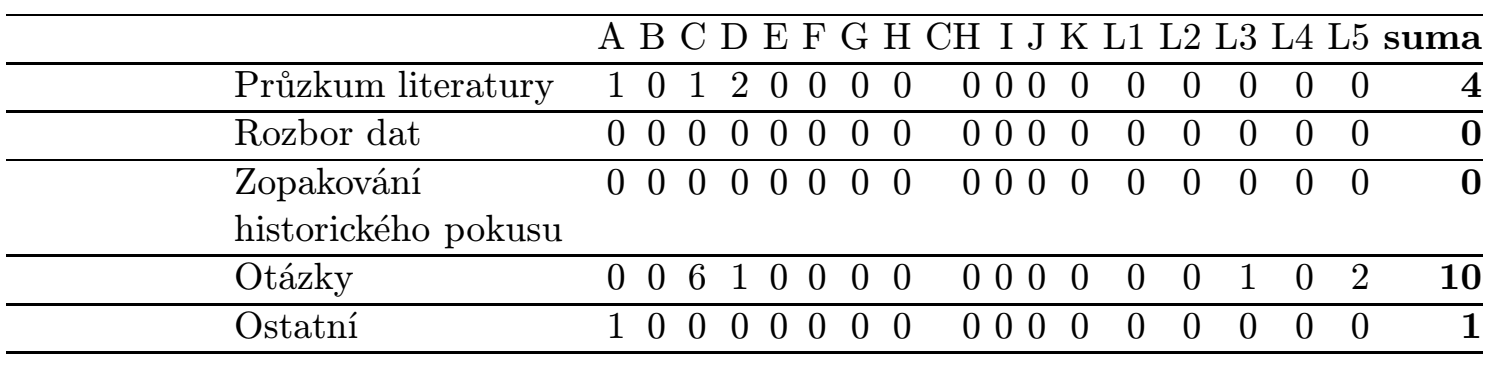

Tab. 7: Bibliografie k historii

\begin{tabular}{lllllllllllllllllllr}
\hline & A & B C & D E F & G H & CH & I J K L1 L2 L3 L4 L5 suma \\
\hline Tištěné publikace & 0 & 0 & 0 & 0 & 0 & 0 & 0 & 0 & 0 & 0 & 0 & 0 & 0 & 0 & 0 & 0 & 1 & $\mathbf{1}$ \\
\hline Internet & 0 & 0 & 5 & 0 & 0 & 0 & 0 & 0 & 0 & 0 & 0 & 0 & 0 & 0 & 0 & 0 & 0 & $\mathbf{5}$ \\
\hline
\end{tabular}

Tab. 8: Způsob zařazení historických pasáží

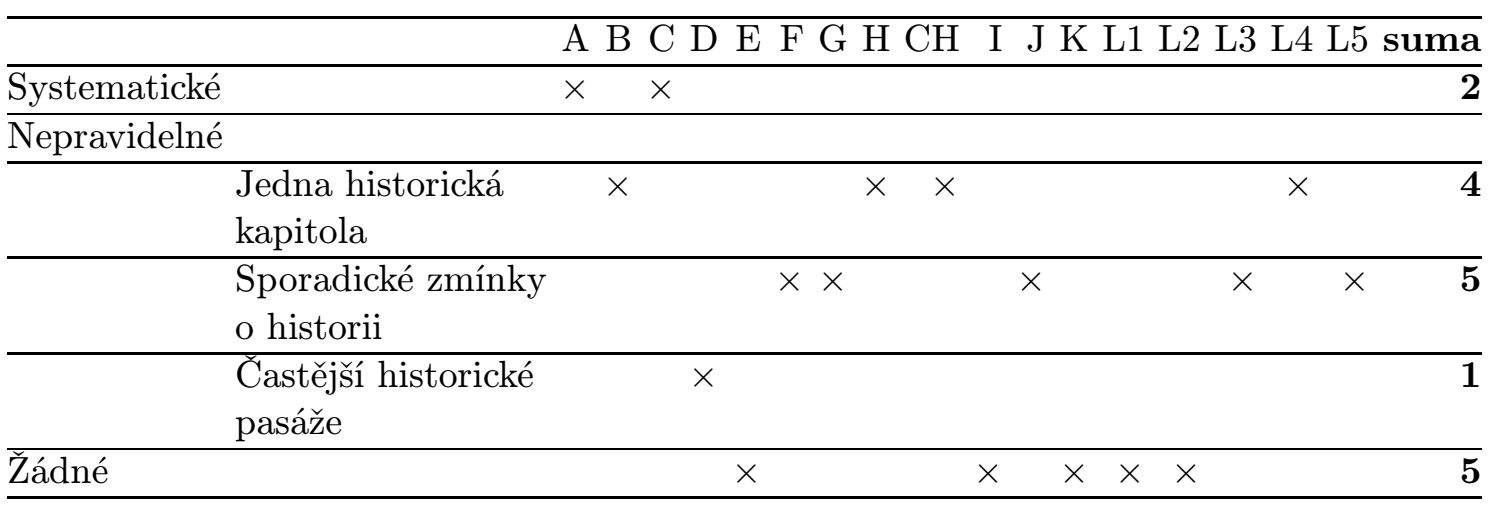

Z tabulky 6 vyplývá, že učebních aktivit na historické téma bývá v učebnicích poskrovnu. Pokud se ojediněle vyskytnou, jde o testové otázky na znalost (tj. prosté vybavení přečtených informací), př́ípadně o výzvu k prostudování literatury a vypracování eseje na historické téma.

Doporučená či použitá literatura vztahující se k historickému vývoji biologie není obvyklou součástí učebnic (viz tab. 7).

U deseti z celkového počtu 17 učebnic bud' zmínky o historii zcela chybí, nebo jsou pouze ojedinělé (viz tab. 8). Žádné historické informace neobsahují učebnice věnované zoologii $(\mathrm{E}, \mathrm{I})$, ekologii $(\mathrm{K})$ a botanice (L1). Naopak nejvíce byly dějiny zohledněny $\mathrm{v}$ biologii člověka $(\mathrm{A})$, genetice $(\mathrm{C})$ a biologii buněk $(\mathrm{D})$. Jak již bylo uvedeno výše, učebnice $\mathrm{A}$ a $\mathrm{C}$ pochází od téhož autora, který dějinám vědy připisuje nemalý význam. S ohledem na stav historického obsahu v ostatních učebnicích z daných oborů $(\mathrm{H}, \mathrm{CH}, \mathrm{J}, \mathrm{G}, \mathrm{L} 4)$ a omezený počet učebnic nelze vyvodit závěr, že by se v určitém oboru věnovala dějinám větší pozornost. Stejně tak z tabulky 8 nelze vypozorovat žádný rozdíl mezi učebnicemi jednotlivých nakladatelství.

\section{Diskuse}

Výsledky z tabulky 8 ukazují, že se soudobé české gymnaziální učebnice biologie hodně liší prostorem, který historii věnují. Učebnice, které ho mají větší, jsou spíše 
ojedinělé, většina učebnic dějiny nezohledňuje bud’ vůbecnebo jen okrajově. Toto zjištění je $\mathrm{v}$ souladu s podobnými výzkumy z jiných zemí: např́íklad podle prací Rutherforda (2001) či Wang a Cox-Petersona (2002) dějiny vědy v učebnicích př́liš zohledněny nejsou. K obdobnému závěru dospěl také Gallagher (1991), podle něhož věnují učebnice vývoji vědeckých myšlenek jen malou pozornost a soustřed’ují se hlavně na fakta.

Podle výzkumu Leite (2002) je v učebnicích prostor věnovaný dějinám vědy různě velký, přičemž většinou jsou historické odkazy mimo hlavní text, což je v souladu $\mathrm{s}$ výsledky uvedenými v tab. 5, a jen málokdy přispívají k adekvátnímu obrázku o vědě. Že jsou v soudobých učebnicích dějiny vědy zmíněny jen okrajově, dokládá také Monk a Osborne (1997). Jejich práce navíc upozorňuje, že historické pasáže nabízejí whigovské pojetí dějin, tj. chápou historický vývoj jako kumulativní pokrok směřující $\mathrm{k}$ vrcholu v podobě moderních výzkumů. Na whigovskou interpretaci dějin, která ne vždy přispívá k porozumění vývoje vědy, naráží také Brush (2000) a tabulka 2 svědčí o její př́tomnosti i v českých učebnicích biologie.

Celkově jsou tedy závěry uvedených studií ve shodě se zjištěními této práce.

\section{ZÁVĚR}

Mnohé výzkumy ukazují, že vzhledem $\mathrm{k}$ vlivu vědy $\mathrm{v}$ dnešním světě je potřeba podporovat vědeckou gramotnost žáků a že se $\mathrm{k}$ dosažení tohoto cíle dá využít dějin vědy. Tyto výzkumy ale také dokládají, že uplatnění této myšlenky v praxi naráží na řadu potíží, mj. na nedostatečné povědomí učitelů o dějinách vědy, a že se v této situaci učitelé velmi spoléhají na učebnice, jejichž kvalita tak může ovlivnit úroveň podání historické problematiky.

$\mathrm{S}$ ohledem na klíčovou roli učebnic mapovala autorka této práce stav českých učebnic. Zkoumány byly recentní učebnice biologie určené vyššímu gymnáziu. Studie ukázala, že se učebnice dosti liší množstvím historického obsahu, nicméně že většina učebnic dějinám věnuje jen okrajovou pozornost. Historické odkazy obvykle představovaly krátké zmínky v nadstavbovém textu o vědci a jemu připisovaném objevu. Pokud učebnice výjimečně popisuje vývoj biologie, jedná se o whigovské pojetí dějin. Takto pojaté dějiny bohužel postrádají příběhy, které mají velký potenciál oživit text učebnice. Podle názoru Hájkové (2016) by pro dobro věci stačilo pár vhodně zvolených historických událostí.

Na životních příbězích jejich aktérů by žáci zakusili povahu dané doby i vědy samotné. Pouze ve dvou učebnicích z celkového počtu 17 byly dějiny biologie skutečně integrální součástí publikace. Výzkum naznačil, že rozdílné začleňování historie je dáno přístupem autora učebnice, vliv nakladatelství či tradice daného biologického oboru v tom podle dostupných údajů nehrají roli.

\section{LITERATURA}

Abd-El-Khalick, F. \& Lederman, N. G. (2000). The infuence of history of science courses on students' views of nature of science. Journal of Research in Science Teaching, 37(10), $1057-1095$.

Brush, S. (2000). Thomas Kuhn as a historian of science. Science $\&$ Education, 9(1), $39-58$. 
Gallagher, J. J. (1991). Perspective and practicing secondary school science teachers' knowledge and beliefs about the philosophy of science. Science Education, 75(1), 121-134.

Hájková, J. (2016). Dějiny biologie - učit, či neučit? Živa, 6, 141-142.

Hodson, D. (1986). Philosophy of science and science education. Journal of Philosophy of Education, 20(2), 215-225.

Holton, G. (2003). What historians of science and science educators can do for one another. Science \& Education, 12(7), 603-616.

Irwin, A. R. (2000). Historical case studies: Teaching the nature of science in context. Science Education, 84(1), 5-26.

Justi, R. \& Gilbert, J. (2000). History and philosophy of science through models: Some challenges in the case of the atom. International Journal of Science Education, 22(9), 993-1009.

Klopfer, L. E. (1969). The teaching of science and the history of science. Journal of Research in Science Teaching, 6(1), 87-95.

Klopfer, L. \& Cooley, W. (1961). Use of case histories in the development of student understanding of science and scientists. Cambridge, Massachusetts: Graduate School of Education, Harvard University.

Kyle, W. C. (1970). Assessing students' understanding of science. Journal of Research in Science Teaching, 34(9), 851-852.

Lederman, N. G. (1992). Students' and teachers' conceptions of the nature of science: A review of the research. Journal of Research in Science Teaching, 29(4), 331-359.

Lederman, N. G. (1995). The influence of teachers' conceptions of the nature of science on classroom practice. In F. Finley et al. (Eds.), Third international history, philosophy and science teaching conference (656-663). Minneapolis: University of Minnesota Press.

Leite, L. (2002). History of science in science education: Development and validation of a checklist for analysing the historical content of science textbooks. Science \& Education, 11(4), 333-359.

Lin, H. S., Hung, J. Y. \& Hung, S. C. (2002). Using the history of science to promote students' problem-solving ability. International Journal of Science Education, 24(5), $453-464$.

Matthews, M. R. (Ed.) (1994). Science teaching: The role of history and philosophy of science. New York: Routledge.

Monk, M. \& Osborne, J. (1997). Placing the history and philosophy of science on the curriculum: A model for the development of pedagogy. Science Education, 81(4), 405-424.

Pella, M. O. et al. (1966), Scientific literacy: Its referents. The Science Teacher, 33(5), 44.

Rutherford, F. J. (2001). Fostering the history of science in American science education. Science \& Education, 10(6), 569-580.

Rutherford, F. \& Ahlgren, A. (1990). Science for all Americans. Oxford, New York: Oxford University Press.

Slezak, P. (1994). Does science teaching need history and philosophy of science? In M. R. Matthews (Ed.), Science teaching: The role of history and philosophy of science (21-38). New York: Routledge. 
Snow, C.P. (1959). Two cultures and the scientific revolution. New York: Cambridge University Press.

Solomon, J. et al. (1992). Teaching about the nature of science through history: Action research in the classroom. Journal of Research in Science Teaching, 29(4), 409-421.

Wandersee, J.H. (1986). Can the history of science help science educators anticipate students' misconceptions? Journal of Research in Science Teaching, 23(7), 581-597.

Wandersee, J. H. (1985). The history phone. Science and Children, 23(1), 15-17.

Wang, H. A. \& Cox-Peterson, A. M. (2002). A comparison of elementary, secondary and student teachers' perceptions and practices related to history of science instruction. Science \& Education, 11(1), 69-81.

Wang, H. A. \& Marsh, D. D. (2002). Science instruction with a humanistic twist: Teachers' perception and practice in using the history of science in their classrooms. Science \& Education, 11(2), 169-189.

JANA HÁJKOVÁ, hajkova6@natur.cuni.cz

Univerzita Karlova, Př́rodovědecká fakulta

Katedra učitelství a didaktiky biologie

Viničná 7, Praha-Nové Město, Česká republika 